\title{
Putting the Financial Crisis and Lending Activity in a Broader Context
}

\author{
Kevin L. Kliesen, Economist
}

S ome economists, policymakers, and pundits view the financial turmoil that began in August 2007 as the worst financial shock to the U.S. economy since the end of World War II. Some even assert that it amounts to the worst financial crisis since the 1930s. Accordingly, the Federal Reserve and other government agencies have taken aggressive actions to support the financial system and spur economic growth. Other economists and analysts, citing continued modest loan growth and relatively few bank failures last year (compared with, say, the late 1980s and early 1990s), do not share this view. Regardless, many banks have announced sharp earnings declines, and the possibility of further financial losses looms large.

A well-functioning financial sector is crucial to the performance of the U.S. economy. In a market-based economy, the financial sector channels the supply of funds from savers to the demands of borrowers, which supports the wealth-creating abilities of the entrepreneurial sector. At the same time, the performance of the financial sector also depends crucially on the health of the U.S. economy. Typically, growth of loans and leases at commercial banks declines sharply before a recession.

Clearly, bank actions to limit the credit supply can exacerbate an economic downturn. For example, banks typically tighten credit standards and/or loan terms as the economy weakens and nonperforming loans increase. But an adverse shock from outside the financial sector can be just as important-such as a sharp increase in oil prices or a plunge in house prices. Such shocks also slow the demand for credit because of weaker future growth of incomes and profits. In large and open economies, forces that trigger changes in the supply and demand for credit are often synchronized and difficult to distinguish.

Thus, it is not surprising that bank loans slowed when GDP growth slowed: When GDP averaged 2.7 percent for 2004-07, the growth of bank loans averaged 11.4 percent per year; when GDP fell slightly in 2008, growth of bank loans slowed to 5.6 percent. Most forecasters expect reces-

sionary conditions through the first half of 2009, so continued weak growth of bank loans is likely. Indeed, in the 1990-91 and 2001 recessions, the year-to-year percentage decline in bank loans did not reach a trough until February 1993 and March 2002, respectively.

\section{"Banks typically tighten credit standards and/or loan terms as the economy weakens and nonperforming loans increase. But an adverse shock from out- side the financial sector can be just as important-such as a sharp increase in oil prices or a plunge in house prices."}

Other factors have weakened household and business spending in the current recession and thus have adversely affected the supply and demand for bank loans. A 52 percent drop in the S\&P 500 stock price index from October 9, 2007, to November 20, 2008, accompanied the oil shock and fall in house prices. Accordingly, household net worth (financial and tangible net wealth) fell by about $\$ 7$ trillion between 2007:Q2 and 2008:Q3. Another key factor has been the simultaneous slowing in economic growth in most of the world's largest economies, which is important because exports were a key source of U.S. economic growth in 2004-07.

Some claim the key cause of slower growth has been the losses and write-downs incurred by banks and other financial institutions that hold asset-backed securities ( $\underline{\mathrm{ABS}}$ ) on their balance sheets. ${ }^{1}$ In particular, prices of nonprime mortgage-related ABS have plummeted in part because of rising mortgage defaults and foreclosures stemming from falling house prices and a weakening economy. Because many of these ABS are no longer actively traded, determining their price-and thus the impact on the banking system's 
lending capacity - has been a key source of the uncertainty in financial markets. As a result, many firms have been extremely cautious in lending because of the perceived risk in lending to parties who may have substantial ABS losses. Some estimate that these losses may eventually exceed $\$ 2$ trillion, but even those estimates depend importantly on the pace of economic recovery. Moreover, not all firms hold ABS on their balance sheets, so the perception of increased credit risk-arising in part from poor macroeconomic conditions-has affected markets more broadly.

A report prepared for the 2008 U.S. Monetary Policy Forum argued that the financial crisis will begin to wane when (i) banks and other financial institutions can raise enough new equity capital to improve their balance sheets and (ii) risk and uncertainty recede enough that firms are less reticent about making loans. ${ }^{2}$ A more stable macroeconomic environment will go far toward achieving this outcome.

\footnotetext{
${ }^{1}$ This development is a by-product of the securitization of a wide swath of the U.S. credit markets that has created a so-called shadow banking system.

2 Greenlaw, David; Hatzius, Jan; Kashyyap, Anil, K. and Shin, Hyun S. "Leveraged Losses: Lessons from the Mortgage Market Meltdown.” U.S. Monetary Policy Forum Report No. 2, 2008; http://faculty.chicagogsb.edu/anil.kashyap/research/ MPFReport-final.pdf.
} 